\title{
И.О. Краснова* ЭКОЛОГИЧЕСКАЯ БЕЗОПАСНОСТЬ КАК ПРАВОВАЯ КАТЕГОРИЯ
}

\begin{abstract}
Аннотачия. Автор раскрывает исторические корни такого правового явления, как экологическая безопасность, определяет проблемы правового регулирования, дает характеристику международно-правовой политике в данной области и ее влиянию на развитие экологического права России в части регулирования отношений экологической безопасности. В статье дана оценка соотношению таких понятий, как промышленная и радиационная безопасность, химическая и биологическая безопасность, экологическая безопасность в чрезвычайных ситуациях. В статье также содержится подробный анализ нормативных правовых актов, регулирующих отношения экологической безопасности, выявлены недостатки правового регулирования. Освещен вопрос о соотношении понятий “охрана окружающей среды» и «экологическая безопасность» в экологическом законодательстве. В итоге автор обосновывает собственное понимание понятия «экологическая безопасность» как наименования института экологического права, определяет его содержание, возможные перспективы его развития.

Ключевые слова: юриспруденция, опасные производственные объекты, радиационная безопасность, экологическая безопасность, чрезвычайные экологические ситуации, охрана окружающей среды, промышленная безопасность, наука экологического права, институт экологической безопасности, генномодифицированные организмы.
\end{abstract}

DOI: 10.7256/1729-5920.2014.5.9506

\section{1. Проблемы правового регулирования}

Сегодня категория «экологическая безопасность» прочно вошла в терминологию экологического права.

В разных контекстах она возникает в Федеральном законе от 10.01.2002 № 7-Ф3 «Об охране окружающей среды»1. Преамбула включает обеспечение экологической безопасности в качестве цели и содержания государственной политики в области охраны окружающей среды. В соответствии со ст. 12 пропаганда деятельности в области обеспечения экологической безопасности является правом общественных экологических объединений.

СЗ РФ. 2002. № 2. Ст. 133.
Обеспечение экологической безопасности провозглашается в качестве цели экологического нормирования (ст. 19), экологической сертификации (ст. 31). Она также входит в состав мероприятий, которые обязаны осуществлять субъекты хозяйственной деятельности (ст. $34,35,40,44,48$ и т.д.).

Обеспечение экологической безопасности предусмотрено и другими законами. К примеру, Федеральный закон от 23.11.1995 № 174-Ф3 «Об экологической экспертизе»² в качестве принципа экологической экспертизы предусматривает обязательный учет требований экологической безопасности при проведении экологической экспертизы. Однако уста-

СЗ РФ. 1995. № 48. Ст. 4556.

\footnotetext{
(C) Краснова Ирина Олеговна

* Доктор юридических наук, профессор кафедры экологического и природоресурсного права Московского государственного юридического университета имени О.Е. Кутафина (МГЮА) [ikrasnova@mail333.com] 123995 г. Москва, ул. Садовая-Кудринская, д. 9.
} 
новить суть этих требований не удается, так как в самом законе нет ни отсылочных норм, ни расшифровки этих требований.

Без детализации экологическая безопасность упоминается в контексте обязанности ее обеспечения при эксплуатации железнодорожного транспорта, внутреннего водного транспорта, объектов топливно-энергетического комплекса.

Наконец, Федеральный закон от 28.12.2010 № 390-Ф3 «О безопасности» ${ }^{3}$ в качестве предмета своего регулирования называет экологическую безопасность наряду с обеспечением безопасности в других сфрерах жизни.

Помимо этого, экологическая безопасность как цель и направление деятельности включена в ряд политических документов - стратегии развития регионов, развития энергетики.

Однако можно ли считать, что уровень и качество правового регулирования отношений в области экологической безопасности являются достаточными? Изучение законодательных положений заставляет думать о том, что законодатель пользуется этим термином хаотично, не имея единого представления ни о содержании, ни о смысле правовой категории экологической безопасности.

Нередко меры обеспечения экологической безопасности в разных сферах выборочно воспроизводят общие требования охраны окружающей среды, закрепленные в Федеральном законе «Об охране окружающей среды» и других экологических законах, называя их, однако, мерами обеспечения экологической безопасности.

К примеру, Кодекс внутреннего водного транспорта РФ 4 в ст. 39 «Обязанности судовладельцев по охране окружающей среды» на самом деле устанавливает обязанности судовладельцев по обеспечению экологической безопасности, а не охраны окружающей среды, вероятно имея в виду, что данные категории являются синонимами. Здесь предусмотрено, что обеспечение экологической безопасности является обязанностью судовладельцев, которая включает принятие мер по предотвращению загрязнения с судов различными отходами, в том числе нефтью и другими вредными веществами, а также ликвидации последствий такого загрязнения. При этом предотвращение загрязнения является общей мерой и требованием в области охраны окружающей среды в соответствии с Законом «Об охране окружающей среды».

\footnotetext{
СЗ РФ. 2011. № 1. Ст. 2.

СЗ РФ. 2001. № 11. Ст. 1001.
}

Федеральный закон от 10.01.2003 № 17Ф3 «О железнодорожном транспорте в Российской Федерации» ${ }^{5}$, возложив обязанность по обеспечению экологической безопасности на различные железнодорожные организации, вообще не разъясняет суть таких работ.

Законодательство об автомобильном транспорте почему-то не пользуется этим термином, хотя автомобильный транспорт является источником повышенной опасности и экологические проблемы, вызываемые эксплуатацией автомобильного транспорта и транспортной инфраструктуры, не менее серьезны и опасны.

Ни как цель, ни как принцип правового регулирования, ни тем более как система правовых мер обеспечение экологической безопасности не упоминается в законодательстве, устанавливающем порядок эксплуатации опасных производственных объектов, источников радиационного излучения, обращения с опасными химическими и биологическими веществами, хотя именно такая деятельность связана с созданием высоких рисков причинения экологического вреда, равно как и вреда здоровью и имуществу населения.

Федеральный закон от 10.07.2001 №92-Ф3 «О специальных экологических программах реабилитации радиационно загрязненных участков территории» ${ }^{6}$ в ст. 5 «Обеспечение экологической безопасности» включает в содержание этого понятия требование о наличии положительного заключения государственной экологической экспертизы для проекта внешнеторговой сделки по ввозу в РФ тепловыделяющих сборок атомных реакторов и предусматривает установление ежегодного лимита на такой ввоз. Известно, что экологическая экспертиза является одной из мер охраны окружающей среды, а не специально обеспечения экологической безопасности, хотя и провозглашена в виде принципа ее проведения Федеральным законом «Об экологической экспертизе».

Одной из целей стандартизации согласно Федеральному закону от 27.12.2002 № 184-Ф3 «О техническом регулировании» ${ }^{7}$ является повышение уровня экологической безопасности, а целью принятия технических регламентов, наряду с иными, является охрана окружающей среды, жизни и здоровья животных и растений. Такие фрормулировки заставляют

\footnotetext{
СЗ РФ. 2003. № 2. Ст. 169.

СЗ РФ. 2001. № 29. Ст. 2947.

СЗ РФ. 2002. № 52 (ч. 1). Ст. 5140.
} 
сделать вывод о том, что смысл понятий «экологическая безопасность» и «охрана окружающей среды» по данному закону различен, хотя ни определений, ни содержания требований в этих сфрерах не раскрывается. При этом в соответствии с принципами стандартизации стандарты, в отличие от технических регламентов, являются документами добровольного применения, т.е. не обладают обязательной юридической силой. Таким образом, достижение экологической безопасности как цели стандартизации зависит от желания и доброй воли самого производителя продукции и других субъектов этих отношений, и, соответственно, экологическая безопасность становится менее значимой, чем обеспечение охраны окружающей среды.

Для созданной в 2012 г. Президентом РФ Комиссии по вопросам стратегии развития ТЭК и экологической безопасности ${ }^{8}$ были определены задачи, в число которых входит, в частности, рассмотрение нормативных правовых актов по вопросам промышленной безопасности, энергетической безопасности, рациональному использованию и охране недр, а также отдельно экологической безопасности. Можно догадываться, что в последнем случае имеется в виду просто рассмотрение этой Комиссией нормативных правовых актов, устанавливающих для объектов ТЭК требования охраны окружающей среды, поскольку отдельно упоминаются промышленная и энергетическая безопасность. Что остается за пределами этих видов безопасности и может быть отнесено к сфере правового регулирования отношений по экологической безопасности - неясно.

Генеральный план города Москвы ${ }^{9}$ имеет раздел 3.6 «Мероприятия по оптимизации качества окружающей среды и обеспечению социальных гарантий жителям в части экологической безопасности», который содержит перечень таких мероприятий, выборочно воспроизводящий некоторые общие меры охраны окружающей среды. Как и в других случаях, разделить предусмотренные этим документом мероприятия в области охраны окружающей среды и экологической безопасности, невозможно.

\footnotetext{
8 Указ Президента РФ от 15.06.2012 № 859 «О Комиссии при Президенте Российской Федерации по вопросам стратегии развития топливно-энергетического комплекса и экологической безопасности» // С3 РФ 2012. № 28. Ст. 3879.

9 Закон г. Москвы от 05.05.2010 № 17 «О Генеральном плане города Москвы» // Ведомости Московской городской Думы. 2010. № 6. Ст. 137 (без приложения).
}

Такому бессистемному использованию термина «экологическая безопасность» способствует и сам Закон «Об охране окружающей среды». Надо сказать, что определение понятия «экологическая безопасность» в этом Законе дано, но оно сформулировано настолько абстрактно, что не позволяет из всего многообразия отношений в области охраны окружающей среды выделить отношения именно экологической безопасности, определить особые права и обязанности субъектов, построить эфффективный механизм реализации правоотношений, включая меры юридической ответственности. Экологическую безопасность как самостоятельную категорию выделить не удается.

Экологическая безопасность определена в ст. 1 Закона «Об охране окружающей среды» как состояние защищенности природной среды и жизненно важных интересов человека от возможного негативного воздействия хозяйственной и иной деятельности, чрезвычайных ситуаций природного и техногенного характера, их последствий. В этом определении отсутствуют критерии оценки состояния защищенности, которые бы позволили в необходимый момент констатировать состояние экологической опасности. Из определения также следует, что достичь и поддерживать такое состояние безопасности можно путем просто надлежащего исполнения экологических требований, т.е. мер охраны окружающей среды в целом, при условии, что такие требования идеально сбалансированы в целой системе права. Кроме того, Закон не содержит ни самостоятельного раздела, ни отдельной статьи, которые бы определяли специальные, дополнительные к иным требованиям в области охраны окружающей среды, требования в области обеспечения экологической безопасности. Все это позволяет констатировать, что экологическая безопасность по замыслу законодателя не имеет самостоятельного значения, не обладает собственным уникальным содержанием, а скорее совпадает с понятием «охрана окружающей среды».

Такая неопределенность понятия «экологическая безопасность», порой смешение его с понятием «охрана окружающей среды» нуждаются в устранении. Свободное жонглирование этими терминами в различных законах засоряет законодательство, создает излишние нормы, исполнение которых по крайней мере непонятно, а в итоге плохо реализуемо, что снижает общую эффрективность правовой охраны окружающей среды в условиях экологической опасности. 
Вероятно, наиболее простым решением было бы сохранить статус-кво, оставляя законодателю и исполнителю простор для любой конкретизации категории «экологическая безопасность» применительно к тем или иным сферам жизни. Но при такой альтернативе свобода усмотрения государственных органов в отсутствие принципиальной правовой основы понятия экологической безопасности и механизма реализации отношений в этой сфере не позволит создать единую систему регулирования отношений в этой области и в результате будет препятствовать реализации экологического законодательства в целом.

Неприемлемость такой альтернативы подтверждается ясно выраженной политической волей обеспечить экологическую безопасность Российской Федерации, хотя само понятие «экологическая безопасность» в политических актах также выражено нечетко.

Основы государственной политики в области экологического развития Российской Федерации на период до 2030 года, утвержденные Президентом РФ 30 апреля 2012 г., провозглашают укрепление правопорядка в области экологической безопасности и охраны окружающей среды одной из стратегических целей развития России. Стратегия национальной безопасности Российской Федерации до 2020 года, утвержденная Указом Президента РФ от 12.05.2009 № $537^{10}$, экологическую безопасность рассматривает как составную часть национальной безопасности. Примечательно, что в первом документе «экологическая безопасность» и «охрана окружающей среды» являются отдельными, не совпадающими и не поглощающими друг друга понятиями, хотя их содержание не раскрыто. Во втором документе охрана окружающей среды как отдельная сфера национальной безопасности вообще не упоминается, хотя в разделе 8 «Экология живых систем и рациональное природопользование» в число стратегических целей экологической безопасности включено сохранение окружающей среды и обеспечение ее защиты, ликвидация экологических последствий хозяйственной деятельности в условиях возрастающей экономической активности и глобальных изменений климата. То есть здесь, наоборот, экологическая безопасность как компонент национальной безопасности рассматривается как общее родовое понятие, в содержание которой входит также охрана окружающей среды.

С Р Р. 2009. № 20. Ст. 2444.
Стратегией развития Арктической зоны Российской Федерации и обеспечения национальной безопасности на период до 2020 года, утвержденной Президентом РФ и опубликованной на сайте Правительства РФ 20 фревраля 2013 г., обеспечение экологической безопасности объявлено в числе приоритетных направлений развития Арктической зоны. В пункте 16 этого документа дан единый перечень видов деятельности в целях достижения экологической безопасности и одновременно охраны окружающей среды. Он не позволяет разделить мероприятия по охране окружающей среды и мероприятия, направленные на обеспечение экологической безопасности.

В контексте энергетической безопасности в соответствии с Энергетической стратегией России на период до 2030 года, утвержденной распоряжением Правительства РФ 13.11.200911, экологическая безопасность функционирования энергетического комплекса рассматривается в качестве одного из главных стратегических ориентиров. Экологическая безопасность здесь включает минимизацию негативного влияния добычи, производства, транспортировки и потребления энергоресурсов на окружающую среду и климат.

Реализация государственной политики по обеспечению экологической безопасности нуждается в адекватном развитии законодательства. Однако какое развитие будет адекватным? Нужно ли идти по пути принятия отдельного закона об экологической безопасности, ограничиться внесением поправок в Федеральный закон «Об охране окружающей среды» либо вообще отказаться от дальнейшей конкретизации этого термина?

Поиск ответа будет полезно начать с исторических корней.

\section{2. История}

Экологическая безопасность как правовая категория - не отечественного происхождения. Впервые этот термин появился в международных отношениях, где экологическая безопасность рассматривалась как фрактор обеспечения мира и глобальной безопасности. В 1984 г. на 12-й сессии Совета управляющих ЮНЕП исполнительный директор этой организации в своем заключительном выступлении указал на связь между экологическими проблемами, с одной стороны, и национальной и международной безопасностью - с другой. Он отметил, что глобальной безопасности

11 СЗ РФ. 2009. № 48. Ст. 5836. 
угрожает не только сокращение производства продуктов питания, трансграничное загрязнение и даже вооруженные конфликты, но и современная деятельность по социально-экономическому развитию, которая может привести к нехватке и загрязнению важнейших природных ресурсов, что, в свою очередь, может стать причиной международных трений.

7 декабря 1987 г. Генеральная Ассамблея ООН приняла Резолюцию 42/93 «Всеобъемлющая система международного мира и безопасности», в которой подчеркнуто, что всеобщая и всеобъемлющая безопасность, которая требует совместных усилий всех без исключения участников международных отношений в имеющих критически важное значение и существенных для международной безопасности и взаимосвязанных областях, включая сохранение окружающей среды. В пункте 10 признано, что «сотрудничество в экологической сфрере должно стать неотъемлемой составной частью всеобъемлющей международной безопасности».

Такой же подход к экологической безопасности как возможной причине политической напряженности и военных конфоликтов выражен и в докладе Международной комиссии по окружающей среде и развитию «Наше общее будущее» ${ }^{12}$. В главе 11 «Мир, безопасность, развитие и окружающая среда» факторами, создающими состояние экологической опасности, названы такие экологические проблемы, как экологическая деградация, исчерпание ресурсов, необходимых для развития, глобальное потепление. Соответственно, устранение этих источников опасности требует от каждого государства мер по охране окружающей среды и рациональному использованию природных ресурсов. Одновременно средством достижения безопасности в мире является укрепление международного сотрудничества. В Докладе отмечается, что «глобальными общими достояниями человечества невозможно управлять из какого-либо одного национального центра: любое суверенное государство не имеет достаточных возможностей, чтобы эффективно предотвращать угрозу разделяемым границами экосистемам. С угрозами экологической безопасности можно бороться только через совместное управление и многосторонние процедуры и организационные механизмы ${ }^{13}$. Таким образом, экологическая безопасность в международном контексте, по сути, совпадала с со-

\footnotetext{
12 Наше общее будущее. М. : Прогресс, 1989

13 Наше общее будущее. С. 269.
}

временным пониманием охраны окружающей среды в России, но обоснованием ее выделения из общего контекста было все же признание экологических проблем как угрозы миру на планете.

Важен и контекст, в котором происходило формирование категории экологической безопасности в международных отношениях и международном экологическом праве. В 80-е гг. на фоне нарастающих проблем загрязнения окружающей среды, истощения природных ресурсов усиливалось ощущение наступления глобального экологического кризиса, катастрофы, способной привести к резкому падению экономики, гибели людей и дестабилизации в мире. Это способствовало тому, что охране окружающей среды в мире стало уделяться особое внимание как средству устранения угрозы экологического кризиса.

В тот период мир потрясли крупные промышленные аварии, повлекшие гибель людей, опасное загрязнение воздуха, воды, продуктов питания. В 1976 г. в городе Севезо (Италия) на химическом предприятии произошел взрыв с выбросом диоксина, в результате загрязнения которым погибли тысячи животных, местные жители получили тяжелые заболевания, а место поражения стало на время непригодным для проживания ${ }^{14}$. В 1984 г. произошла крупнейшая по числу жертв (18 тысяч человек) техногенная катастрофа на химическом заводе в городе Бхопал (Индия), производившем инсектициды ${ }^{15}$. В 1986 г. уже в СССР, на территории современной Украины, произошла крупнейшая радиационная авария - взрыв энергоблока на Чернобыльской АЭС. В результате погибли и лишились жилища люди, оказались зараженными радионуклидами значительные территории.

Промышленные аварии подтолкнули государства и международное сообщество разработать специальные правовые меры, направленные на предупреждение аварий, устранение их последствий, главным образом в целях защиты окружающей среды и населения от их разрушительных воздействий.

В 1982 г. Советом ЕЭС была принята Директива 82/501/ЕЭС о контроле крупных аварий, связанных с опасными веществами (Севезо), предусматривавшая жесткие меры контроля за деятельностью опасных промышленных предприятий. В целях адаптации

\footnotetext{
14 Итальянская Хиросима // Newchemistry. URL: http:// www.newchemistry.ru/letter.php?n_id=232.

15 Бхопальская катастрофа // Википедия. URL: http:// ru.wikipedia.org.
} 
к меняющимся на территории современного Европейского Союза политическим, экономическим и экологическим условиям данная директива в 1996 г. была принята в новой редакции - Директива 96/82/EC (Севезо II), а в 2012 г. заменена Директивой 2012/18/EC о контроле крупных аварий, связанных с опасными веществами, изменяющая и впоследствии отменяющая Директиву 96/82/EC.

После Чернобыльской катастрофы еще в РСФСР в 1991 г. был принят закон о социальной защите пострадавших граждан.

В 1992 г. заключена Конвенция о трансграничном воздействии промышленных аварий ${ }^{16}$, где была предусмотрена система мер безопасной эксплуатации предприятий в целях «предотвращения серьезного вредного воздействия промышленных аварий на людей и окружающую среду». В 1997 г. в России принят Федеральный закон от 21.07.1997 № 116Ф3 «О промышленной безопасности опасных производственных объектов» ${ }^{17}$, в определенной степени заимствовавший положения Директивы Севезо и одновременно нацеленный на исполнение Конвенции о трансграничном воздействии промышленных аварий.

Таким образом, экологическая безопасность приобрела двойное значение. С одной стороны, экологическая безопасность - это, по сути, благоприятное состояние окружающей среды, которое обеспечивается общими мерами охраны окружающей среды, обращенными ко всем субъектам. С другой - это отсутствие риска возникновения опасных нештатных ситуаций на промышленных предприятиях, при осуществлении некоторых видов деятельности, грозящих разрушением экосистем, причинением крупного экологического и имущественного ущерба и, конечно, опасных для жизни и здоровья людей. Соответственно, требования экологической безопасности обращены только к субъектам экологически опасной хозяйственной деятельности.

Эти два направления в развитии экологического права на международном уровне повлияли и на формирование правовой категории экологической безопасности в России, которая сегодня приобрела также двойной смысл.

Впервые экологическая безопасность упоминается еще в постановлении ЦК КПСС и

16 Бюллетень международных договоров. 2000. № 6. С. 19-46 (Конвенция ратифицирована постановлением Правительства РФ от 04.11.1993 № 1118, вступила в силу для России 19.04.2000).

7 СЗ РФ. 1997. № 30. Ст. 3588.
Совета министров СССР от 07.01.1988 № 32 «О коренной перестройке дела охраны природы в стране», где указано, что «борьба за экологическую безопасность на Земле должна рассматриваться как одна из самых ответственных и благородных задач советских людей ${ }^{18}$.

Затем это понятие появляется в Законе РСФСР от 19.12.1991 № 2060-1 «Об охране окружающей природной среды ${ }^{19}$, где обеспечение экологической безопасности провозглашается в качестве цели охраны окружающей среды, достижению которой должен способствовать закон. Закон не раскрыл содержания новой правовой категории и не установил требований экологической безопасности, предусмотрев, однако, юридическую ответственность за их нарушение.

Как цель правового регулирования экологических отношений это понятие могло бы, наверно, существовать и далее, но принятие Конституции РФ, ст. 72 которой обеспечение экологической безопасности наряду с охраной окружающей среды включила в сферу совместного ведения Федерации и ее субъектов, потребовало более внимательного отношения к нему.

В этот же период активно развивается законодательство, направленное на решение проблемы техногенных аварий и природных катастрофр. В 1994 г. подготовлены концепция и проект закона «Об экологической безопасности», в котором экологическая безопасность понималась как самостоятельная задача и область отношений, связанных с недопущением и реагированием на ситуации «экологической опасности», характеризующиеся вероятностью разрушения, изменения состояния окружающей природной среды под влиянием природных и антропогенных факторов. Таким образом, экологическая безопасность получает новое, более узкое понимание, соответственно требуя развития специального законодательства.

Хотя закон так и не был принят, в последующий период в духе нового подхода принимается ряд действующих ныне законов, устанавливающих требования безопасности к отдельным опасным видам хозяйственной деятельности. Поскольку любая техногенная и природная катастрофа имеет разрушительные последствия для окружающей среды и жизни людей, общие требования безопасности, предъявляемые к соответ-

18 СП СССР. 1988. № 6. Ст. 14.

19 Ведомости СНД и ВС РФ. 1992. № 10. Ст. 457. 
ствующим объектам, стали именоваться в доктрине экологического права экологической безопасностью.

В этой неоднозначной ситуации в системе правового регулирования остается ответить на вопросы - какое место в экологическом законодательстве должны занять отношения экологической безопасности и какого содержания должны быть требования к субъектам этих отношений?

\section{3. Наука}

В теории экологического права, которая внимательно анализирует законодательство и тенденции его развития, не утихает дискуссия.

Впервые в 1988 г. к исследованию экологической безопасности обращается известный ученый юрист-эколог профессор О.С. Колбасов в статье «Концепция экологической безопасности (юридический аспект)» ${ }^{20}$. Экологическая безопасность рассматривается автором как производная категория от международной безопасности. Ее цель - предупредить ослабление положения СССР в мире, которое может быть вызвано резким или даже постепенным ухудшением экологических условий на нашей территории, а также оградить страну, в том числе мерами защиты суверенитета, от внешних экологических дестабилизирующих факторов. Для создания системы экологической безопасности, по мнению О.С. Колбасова, необходимо как развитие международного сотрудничества по охране окружающей среды, так и укрепление экологического правопорядка в целом на территории страны. Хотя автор не выделяет отношения экологической безопасности из общей системы экологических отношений, в статье дан оценочный критерий определения экологической обстановки как экологически опасной. Это - угроза массовой гибели людей. Из чего можно сделать вывод о том, что законодательство об экологической безопасности в системе экологического законодательства должно регулировать отношения по предупреждению экстремальных ситуаций, вызываемых резким ухудшением экологической обстановки и угрожающих жизни людей.

В современной науке сложилось две позиции о месте отношений экологической безопасности в системе российского экологического права. С одной позиции экологическая безопасность рассматривается как деятельность по охране окружающей среды

20 Советское государство и право. № 12. 1988. С. 47-55 и рациональному использованию природных ресурсов, т.е. деятельность по реализации общих экологических требований. Существование экологической безопасности как самостоятельной правовой категории отрицается. В частности, А.К. Голиченков определяет экологическую безопасность как «форму экологической деятельности, содержание которой составляют достижение и поддержание такого качества окружающей природной среды, при котором воздействие ее факторов обеспечивает здоровье человека и его плодотворную жизнедеятельность в гармонии с природой, а в практическом смысле - сведение (снижение) до возможно малой вероятности опасности вредного воздействия неблагоприятных факторов окружающей природной среды или вероятности экологических аварий и катастроф с помощью системы адекватных мер экономического, политического организационного, правового и иного характера на здоровье человека и другие объекты экологической безопасности» ${ }^{21}$. Аналогичный смысл в понятие экологической безопасности вкладывает и М.М. Бринчук. Так, обеспечение экологической безопасности - «деятельность по охране окружающей среды и рациональному использованию природных ресурсов, отвечающую интересам сохранения благоприятного состояния окружающей среды, а также по защите экологических прав и законных интересов физических и юридических лиц» 22 .

Другая позиция, наоборот, исходит из признания экологической безопасности как особой сферы общественных отношений, составляющих предмет отдельного института в системе экологического права. Объектом этих отношений выступает не любая деятельность, а только та, которая обладает высоким риском причинения значительного экологического вреда. Этой точки зрения придерживается Т.В. Петрова, которая отмечает, что «задачи обеспечения экологической безопасности несколько уж́же, чем задачи охраны окружающей среды, и не связаны с восстановлением природной среды, с обеспечением рационального использования и воспроизводства

21 Голиченков А.К. Охрана окружающей среды, обеспечение экологической безопасности, обеспечение рационального использования природных ресурсов: термины, содержание, соотношение // Сборник материалов всероссийских научно-практических конференций «Софрино», 1995-2004. Юбилейный выпуск. М., 2004 T. 1. C. 125.

22 Бринчук М.М. Роль государства в обеспечение экологической безопасности // Экологическая безопасность, проблемы, поиск, решения. М., 2001. С. 106-119. 
природных ресурсов. Они в значительной степени сводятся к сохранению такого состояния природной среды, при котором не нарушаются жизненно важные интересы человека, проживающего в этой среде» ${ }^{23}$.

Такое узкое понимание категории экологической безопасности поддерживает и Н.Г. Жаворонкова. По ее мнению, «содержание института экологической безопасности не может рассматриваться вне контекста общих требований экологического законодательства, понимаемого достаточно широко и включающего в себя весь спектр нормативных правовых актов, относящихся к проблемам охраны окружающей среды и природопользования.

Экологическое право как отрасль права шире, чем совокупность общественных отношений, составляющих содержание института экологической безопасности, и тем более шире права чрезвычайных ситуаций. Оно включает такие традиционные институты, как право собственности на природные ресурсы, право природопользования, экологическое управление, охрану и использование природных ресурсов (земля, вода, недра, атмосферный воздух и др.). В то же время обеспечение экологической безопасности преследует особые цели и задачи, обусловленные, вопервых, повышенной степенью опасности антропогенной деятельности для окружающей природной среды, жизни и здоровья граждан, во-вторых, чрезвычайными ситуациями природного и техногенного характера. Таким образом, обеспечение экологической безопасности связано с соблюдением экологических требований законодательства в области размещения и эксплуатации хозяйственных и иных объектов, могущих или оказывающих существенное негативное воздействие на окружающую среду, а также обращения с опасными веществами, микроорганизмами, ядерными объектами, объектами генно-инженерной деятельности - т.е. особым предметом правового регулирования, имеющим свою специфику, свой объект, свои особые нормы» ${ }^{24}$.

Ни одна из предложенных позиций не может быть безоговорочно отвергнута, так как само законодательство подтверждает каждую

23 Петрова Т.В. Техническое регулирование как часть системы правового регулирования отношений в сфере охраны окружающей среды // Экологическое право. Специальный выпуск. 2005. № 1. С. 79.

24 Жаворонкова Н.Г. Эколого-правовые проблемы обеспечения безопасности при чрезвычайных ситуациях природного и техногенного характера : дис. ... д-ра юрид- наук. М., 2007. С. 83-84. из них. Но и сохранять такое положение неразумно, поскольку задача обеспечить экологическую безопасность наряду с охраной окружающей среды остается.

Если попытаться систематизировать уже проделанную титаническую работу наших ученых по этому вопросу, а также действующее законодательство, то можно предложить следующее.

Экологическая безопасность не может быть вычеркнута из системы международного права и должна входить в виде цели международного сотрудничества в области международной безопасности. Концепция национальной безопасности ясно определяет средства и способы решения этой задачи. Но следует исходить из понимания, что экологическая безопасность России- это защита жизненно важных интересов природной среды человека от внешних угроз экологического характера в законодательстве о безопасности страны. Экологическая безопасность становится категорией международного права.

Одновременно существует потребность обеспечить и экологическую безопасность внутри страны, в том числе для укрепления экологической безопасности России в международных отношениях. Эта потребность обусловлена нашими внутренними интересами жить в благоприятных природных условиях и не испытывать чувства опасности от разрушаемой нами природы. В противном случае также возможны крайне негативные экономические, социальные последствия для людей и инфраструктуры, грозящие одновременно ослаблением России как суверенного государства. В этом смысле экологическую безопасность следует рассматривать как принцип развития экологического законодательства в целом.

Реализация этого принципа, однако, должна быть облачена в ясно выраженные юридические фрормы. Все же само слово «опасность» заставляет из всех видов деятельности выделить именно те, которые несут в себе риск наступления событий, «угрожающих жизни и имуществу человека, его правам и интересам ${ }^{25}$. При этом нужно исходить из того, что состояние безопасности не может быть застывшим и единожды достигнутым. Наоборот - это динамичный баланс между масштабами и темпами социально-экономического развития и мерами предотвращения опасной деградации окружающей среды. Поддерживать такой баланс

25 Опасность // Википедия. URL: http://ru.wikipedia.org. 
постоянно в условиях объективных факторов развития общества на неизменном уровне невозможно. Современная жизнь характеризуется резким ростом или падением экономик, постепенным или резким истощением жизненно важных природных ресурсов при ускоренных темпах роста потребностей и, соответственно, стремлением их удовлетворить, франтастическим научно-техническим прогрессом, несущим немыслимые когда-то блага для людей и одновременно таящим неизвестные науке угрозы тем же благам.

Поэтому круг субъектов, к которым должны быть обращены особые требования экологической безопасности, не может быть застывшим. Законодатель должен предусмотреть возможность включения в этот круг и исключения из него соответствующих видов деятельности. На данный момент мы можем говорить о том, что в число этих видов деятельности входят эксплуатация опасных производственных объектов, источников ионизирующего излучения, производство опасных химических и биологических веществ, в том числе генномодифицированных организмов, обращение с опасными отходами. Не исключено, что в будущем в число субъектов могут войти некоторые природопользователи, которые сегодня руководствуются общими, а не экстренными правилами природопользования. Например, истощение месторождений энергоресурсов и других полезных ископаемых может стать угрозой энергетической безопасности и потребует от законодателя чрезвычайных мер добычи полезных ископаемых или даже ограничения их экспорта. Одновременно из числа субъектов могут быть исключены некоторые виды деятельности. Так, возможности науки и технологий снять угрозу радиационных аварий, обеспечить полную и долгосрочную изоляцию радиоактивных веществ и отходов, а может, вовсе отказаться от использования радиоактивных веществ для производства энергии снимут проблему радиационной безопасности, позволят исключить эту деятельность из списка экологически опасных. Отказ от производства химического оружия и его полное уничтожение на территории России в соответствии с международными обязательствами по Конвенции о запрещении разработки, производства, накопления и применения химического оружия и о его уничтожения (13.12.1993, Париж) ${ }^{26}$ также потребуют

26 Бюллетень международных договоров. 1998. № 4 (Конвенция ратифицирована Федеральным законом от 05.11.1997 № 138-Ф3 // СЗ РФ. 1997. № 45. Ст. 5138). корректировки списков экологически опасных видов деятельности.

Если речь идет об угрозе жизни и развитию, то и требования экологической безопасности, предъявляемые к таким субъектам, должны быть особыми, т.е. должны выходить за пределы требований охраны окружающей среды, предусмотренные для всех. Сегодня это тоже есть в законодательстве. Однако законодатель запутывает нас тем, что объединяет эти особые требования под общими названиями - промышленная безопасность, радиационная безопасность, биологическая безопасность и т.д. Но это не препятствует считать промышленную безопасность составной частью экологической безопасности, так как суть требований, установленных в законе, - в первую очередь именно в предупреждении риска гибели людей, масштабного загрязнения или иной деградации окружающей среды, которая станет непригодной для жизнеобеспечения людей в результате аварии на промышленном предприятии. Окружающая среда, загрязненная радионуклидами вследствие нарушения правил эксплуатации либо аварийной ситуацией на АЭС или иных источниках ионизирующего излучения, становится опасной для жизни и хозяйственной деятельности людей. Поэтому специальные меры обеспечения безопасности АЭС, нацеленные на предупреждение опасного воздействия аварийных ситуаций на окружающую среду, являются мерами экологической безопасности.

Опасны для общества и природные катаклизмы, число и масштабы которых несут все возрастающие угрозы. Здесь тоже действует система чрезвычайных мер как прогнозирования, так и реагирования на эти ситуации.

Bce вышесказанное приводит к выводу о том, что нормы, регулирующие отношения экологической безопасности, уже сформировали самостоятельный институт в системе экологического права. По содержанию это особые требования, нацеленные на поддержание такого состояния экологически опасной хозяйственной деятельности, при котором опасность возникновения аварий с разрушительными последствиями для человека и окружающей среды отсутствует либо сведена к минимуму. В систему этого института также входят нормы, определяющие порядок действий при наступлении природных и техногенных катастроф, а также прогнозирование таких ситуаций и обеспечение готовности к действиям по устранению их последствий и снижению их опасности. 


\section{4. Экологическая безопасность} как институт экологического права

Современное состояние развития института экологической безопасности в системе экологического права можно охарактеризовать следующим образом.

Если исходить из определения экологической безопасности, данного Федеральным законом «Об охране окружающей среды», то источниками экологической опасности и, соответственно, объектами общественных отношений в области экологической безопасности выступают хозяйственная деятельность, которая способна оказать негативное воздействие на окружающую среду и жизненно важные интересы человека, и чрезвычайные ситуации природного и техногенного характера.

Виды хозяйственной деятельности, представляющие экологическую опасность, как объекты отношений экологической безопасности и требования к их осуществлению определяются специальными законами в каждом конкретном случае. При этом следует подчеркнуть, что основным признаком, позволяющим выделить объекты отношений экологической безопасности в особую группу с установлением особых требований к их осуществлению, является риск возникновения аварий с разрушительными последствиями для окружающей среды и жизни человека. В число таких видов деятельности входит деятельность, связанная с эксплуатацией опасных производственных объектов (включая специально эксплуатацию гидротехнических сооружений), радиационных установок, иных объектов ионизирующего излучения (включая хранилища радиоактивных отходов), связанная с обращением с опасными химическими и биологическими веществами и организмами (включая генномодифицированные организмы), опасными твердыми и радиоактивными отходами. В особую группу отношений в системе экологической безопасности выделяется деятельность по организации действий в чрезвычайных ситуациях при наступлении производственных аварий и природных катастроф. Сама эта деятельность не является экологически опасной, но она органически связана с мерами предупреждения производственных аварий и природных катастроф, а в силу определенной самостоятельности этих мер (реализуются с участием МЧС России) образует еще один вид деятельности по обеспечению экологической безопасности.

Исходя из такой классификации видов деятельности, как объектов отношений экологи- ческой безопасности в теоретическом плане, можно выделить такие виды экологической безопасности, как промышленная безопасность (включая безопасность в гидроэнергетике), радиационная безопасность, химическая и биологическая безопасность (включая безопасность обращения с опасными отходами производства и потребления, радиоактивными отходами), безопасность в чрезвычайных ситуациях.

Правовые нормы, регулирующие отношения экологической безопасности, закреплены в законодательстве. В составе экологического законодательства они образуют относительно самостоятельную отрасль, которую можно именовать пока в теории законодательством об экологической безопасности. Оно сегодня развивается по пути секторального регулирования, т.е. посредством установления правовых требований экологической безопасности отдельными законами по каждому сектору экономики или виду опасной хозяйственной деятельности. Так, экологическую безопасность в промышленности обеспечивают Федеральные законы от 21.07.1997 № 116-Ф3 «О промышленной безопасности опасных производственных объектов» и от 21.07.1997 № 117-Ф3 «О безопасности гидротехнических сооружений» ${ }^{27}$. Меры радиационной безопасности предусмотрены Федеральными законами от 09.01.1996 № 3-Ф3 «О радиационной безопасности населения» ${ }^{28}$, от 21.11.1995 № 170Ф3 «Об использовании атомной энергии» ${ }^{29}$, от 10.07.2001 № 92-Ф3 «О специальных экологических программах реабилитации радиационно загрязненных участков территории» ${ }^{30}$.

Экологическая безопасность при обращении с опасными химическими и биологическими веществами обеспечивается главным образом подзаконными актами, принимаемыми на основе Федерального закона «Об охране окружающей среды». Одновременно отношения по обращению с отдельными видами химических и биологических веществ регулируются фредеральными законами. Например, требования по использованию химических веществ в сельском хозяйстве установлены Федеральными законом от 19.07.1997 № 109-Ф3 «О безопасном обращении с пестицидами и агрохимикатами» ${ }^{31}$, по производству генномо-

\footnotetext{
С3 РФ. 1997. № 30. Ст. 3589.

28 СЗ РФ. 1996. № 3. СТ. 141.

29 СЗ РФ. 1995. № 48. Ст. 4552.

$30 \quad$ CЗ РФ. 2001. № 29. СТ. 2947.

1 С3 РФ. 1997. № 29. Ст. 3510.
} 
дифицированных организмов - Федеральным законом от 05.07.1996 № 86-Ф3 «О государственном регулировании в области генноинженерной деятельности» ${ }^{32}$. Деятельность в соответствии с международными обязательствами России по устранению опасности накопленного химического оружия обеспечивается Федеральным законом от 02.05.1997 № 76-Ф3 «Об уничтожении химического оружия» ${ }^{33}$. Поскольку закон касается только уничтожения химического оружия, на другие виды деятельности относительно химического оружия (разработку, производство, накопление и применение) распространяется запрет, прямо установленный Конвенцией.

Меры по устранению экологической опасности различных отходов установлены Федеральными законами от 24.06.1998 № 89-Ф3 «Об отходах производства и потребления» ${ }^{34}$ в части регулирования отношений по обращению с опасными твердыми отходами, и от 11.07.2011 № 190-Ф3 «Об обращении с радиоактивными отходами и о внесении изменений в отдельные законодательные акты Российской Федерации» ${ }^{35}$.

Устранение экологической опасности в условиях чрезвычайных ситуаций предусмотрено Федеральным законом от 21.12.1994 № 68-Ф3 «О защите населения и территорий от чрезвычайных ситуаций природного и техногенного характера» ${ }^{36}$, который определяет функционирование единой государственной системы предупреждения и ликвидации чрезвычайных ситуаций. Обязанности субъектов, эксплуатирующих опасные объекты, по устранению последствий в случае наступления аварий на таких объектах предусмотрены Федеральными законами «О промышленной безопасности опасных производственных объектов», «О безопасности гидротехнических сооружений» и «О радиационной безопасности населения».

Как видим, законодательство об экологической безопасности достигло достаточно высокого уровня развития. При этом следует еще раз подчеркнуть, что во многих вышеназванных законах термин «экологическая безопасность» даже не упоминается, хотя само их содержание свидетельствует о том, что они направлены на поддержание состояния защи-

\footnotetext{
СЗ РФ. 1996. № 28. Ст. 3348.

СЗ РФ. 1997. № 18. Ст. 2105.

34 СЗ РФ. 1998. № 26. Ст. 3009.

35 СЗ РФ. 2011. № 29. Ст. 4281.

36 СЗ РФ. 1994. № 35. Ст. 3648.
}

щенности населения и имущества от резкого масштабного негативного воздействия на окружающую среду, а объектом их регулирования выступают источники такого потенциального воздействия - экологически опасные виды деятельности.

С учетом риска наступления опасных экологических последствий (существенное загрязнение окружающей среды, уничтожение или повреждение природных объектов и, как следствие, причинение значительного вреда здоровью и имуществу) в результате аварийных нештатных ситуаций при осуществлении этих видов деятельности законодательство устанавливает для них дополнительные требования. При этом, осуществляя экологически опасные виды деятельности, субъекты обязаны соблюдать и общие требования охраны окружающей среды, такие как нормирование, мониторинг и др.

Несмотря на технические и иные различия в регулируемых видах деятельности и необходимость учета особенностей их осуществления и воздействия на окружающую среду, система требований экологической безопасности обладает и определенным единообразием. Так, подавляющее большинство экологически опасных видов деятельности подлежит государственному лицензированию. Предусмотрен учет экологически опасных объектов путем их государственной регистрации. Для опасных производственных объектов, гидротехнических сооружений и объектов использования атомной энергии установлено обязательное страхование ответственности за причинение вреда здоровью и имуществу граждан. Гражданско-правовая ответственность наступает без вины. По отношению к экологически опасным объектам, потенциально опасной продукции предусмотрены дополнительные меры предупредительного контроля в виде специальных экспертиз, токсиколого-гигиенических и токсикологических исследований, регистрационных испытаний как условия их регистрации. Субъекты, эксплуатирующие экологически опасные предприятия, обязаны разработать и организовать действия в чрезвычайных ситуациях.

Таким образом, признание системы норм, регулирующих отношения экологической безопасности, в качестве института экологического права снимет проблему неопределенности понятия экологической безопасности как правовой категории, ее соотношения с понятием охраны окружающей среды. Это позволит четко определить круг субъектов экологически опасной хозяйственной деятельности, 
их права и обязанности в сфере обеспечения экологической безопасности, а также суть требований, которые они обязаны соблюдать. Государственные меры обеспечения экологической безопасности тоже приобретут опре- деленность. В целях совершенствования законодательства в этом русле будет полезным кодифицировать имеющиеся правовые нормы в составе отдельной главы Федерального закона «Об охране окружающей среды».

\section{Библиография:}

1. Bogoliubov S.A. Kichigin N.V. Zakonodatelnoe regulirovanie deiatelnosti federalnyh organov ispolnitelnoi vlasti po obespecheniu ekologicheskoi bezopasnosti. M., 2007.

2. Baidakov S.L. Stanovlenie i napravlenia razvitiya pravovyh osnov obespechenia ekologicheskoi bezopanosti // Nauchnye trudy MNEPU. 2001. Vyp. 7.

3. Efimova E.I. Ekologicheskoe pravo Rossii. Bibliografia (1958-2004). M., 2007.

4. Platonov Ju.N. Ekologicheskaya komponenta natsionalnoi bezopasnosti Rossii // Zhurnal rossiiskogo prava. \# 8. 2011.

5. Bobylev S.N., Girusov E.V., Perelev R.A., Kretsu N.S. Ekonomika ustoichivogo razvitiya. Uchebnoe posobie. M., 2004.

6. Kotko A.A. Vkliuchenie ekosistemnyh uslug $v$ ekonomicheskie otnoshenia // Izvestia RAN. Geograficheskaya seria. 2009. \# 4.

7. Nashe obschee buduschee. Doklad Mezhdunarodnoi komissii po okruzhaiuchei srede i razvitiu (MKOSR). Perevod s angl. / Pod red. S.A. Evteeva, R.A. Pereleta. M., 1989.

8. Prohozhev A.A. Strategia natsionalnoi bezopasnosti Rossiyskoi Federatsii do 2020 goda i vozmozhnosti ee realizatsii // Natsionalnaya bezopasnost Rossii v usloviyah transformatsii mezhdunarodnyh otnoshenii. M., 2009.

9. Brinchuk M.M. Obespechenie ekologicheskoi bezopasnosti kak pravovaya kategoria // Gosudarstvo i pravo. 2008. № 9. S. 30-42.

10. Rusin S.N. Kontseptualinay problem ekologicheskoi bezopasnosti i gosudarstvennaia ekologicheskaya politika (pravovoi aspect) // Ekologicheskoe pravo. 2010. \# 5.

11. Jarass H.D. Ekologicheskoe pravo i ekologicheskaya bezopasnost kak osnovy bezopasnosti naselenia // Ekologicheskaia bezopasnost: problem zakonodatelnogo obespechenia. Materialy rossiisko-germanskogo teoreticheskogo seminara. Moskva, 15-17 ijunia 1994. S. 22-28.

12. Zhavoronkova N.G. Ekologo-pravovye problemy obespechenia bezopasnosti pri chrezvychainyh situatsiah prirodnogo i tehnogennogo haraktera. M. : Jurisprudentsia, 2007.

13. Golichenkov A.K. Ohrana okruzhaiuschei sredy, obespechenie ekologicheskoi bezopasnosti, obespechenie ratsionalnogo ispolzovania prirodnyh resursov: terminy, soderzhanie, sootnoshenie. Sbornik materialov vserossiiskih nauchno-praktichekih konferentsii "Sofrino" 1995-2004. T. 1. S. 125.

14. Brinchuk M.M. Rol gosudarstva v obespechenii ekologicheskoi bezopasnosti. Ekologicheskaya bezopasnost: problemy, poisk, reshenia. M.

15. Petrova T.V. Technicheskoe regulirovanie kak chast sistemy pravovogo regulirovania otnoshenii v sfere ohrany okruzhaiuschei sredy. Ekologicheskoe pravo. Spestialnyi vypusk. 2005.

16. Kolbasov O.S. Kontseptsia ekologicheskoi bezopasnosti //Sovetskoe gosudarstvo i pravo. \# 12. 1988. S. 47-55.

17. Ponomarev M.V. Pravovoe regulirovanie ekologicheski bezopasnogo obraschenia s othodami v gorodah //Zakonodatelstvo i ekonomika. 2013. № 2.

18. Patiukov A.V. Aktyualnye voporosy realizatsii prava cheloveka na blagopriatnuiu okruzhaiuschuu sredu I ekologicheskuiu bezopasnost $v$ Poslanii Prezidenta Rossii Federalnomu Sobraniu Rossiiskoi Federatsii // Ekologicheskoe pravo. 2011. № 5.

19. Платонов Ю.Н. Экономическая компонента национальной безопасности России // Журнал российского права. - 2011. - № 8.

20. Гончаров В.В/ Обеспечение экологической безопасности в Российской Федерации как перспективный приоритетный национальный проект // Юрист. - 2010. - № 5.

\section{References:}

1. Bogoliubov S.A. Kichigin N.V. Zakonodatelnoe regulirovanie deiatelnosti federalnyh organov ispolnitelnoi vlasti po obespecheniu ekologicheskoi bezopasnosti. M., 2007. 
2. Baidakov S.L. Stanovlenie I napravlenia razvitiya pravovyh osnov obespechenia ekologicheskoi bezopanosti//Nauchnye trudy MNEPU. 2001. Vyp. 7.

3. Efimova E.I. Ekologicheskoe pravo Rossii. Bibliografia (1958-2004). M., 2007.

4. Platonov Ju.N. Ekologicheskaya komponenta natsionalnoi bezopasnosti Rossii. Zhurnal rossiiskogo prava. \# 8. 2011.

5. Bobylev S.N., Girusov E.V., Perelev R.A., Kretsu N.S. Ekonomika ustoichivogo razvitiya. Uchebnoi posobie. M., 2004.

6. Kotko A.A. Vkliuchenie ekosistemnyh uslug $v$ ekonomicheskie otnoshenia//lzvestia RAN. Geograficheskaya seria. 2009. \# 4.

7. Nashe obschee buduschee. Doklad Mezhdunarodnoi komissii po okruzhaiuachei srede b razvitiu (MKOSR). Perevod s angl. / Pod red. S.A. Evteeva, R.A. Pereleta. M., 1989.

8. Prohozhev A.A. Strategia natsionalnoi bezopasnosti Rossiyskoi Federatsii do 2020 goda I vozmozhnosti ee realizatsii // Natsionalnaya bezopasnost Rossii v usloviyah transformatsii mezhdunarodnyh otnoshenii. M., 2009.

9. Brinchuk M.M. Obespechenie ekologicheskoi bezopasnosti kak pravovaya kategoria// Gosudarstvo i pravo. 2008. № 9. S. 30-42.

10. Rusin S.N. Kontseptualinay problem ekologicheskoi bezopasnosti b gosudarstvennaia ekologicheskaya politika (pravovoi aspect).//Ekologicheskoe pravo. 2010. \# 5.

11. Jarass H.D. Ekologicheskoe pravo I ekologicheskaya bezopasnost kak osnovy bezopasnosti naselenia.//Ekologicheskaia bezopasnost: problem zakonodatelnogo obespechenia. Materialy possiisko-germanskogo teoreticheskogo seminara. Moskva, 15-17 ijunia 1994. S.22-28

12. Zhavoronkova N.G. Ekologo-pravovye problem obespechenia bezopasnosti pri chrezvychainyh situatsiah prirodnogo I tehnogennogo haraktera. M., Jurisprudentsia. 2007

13. Golichenkov A.K. Ohrana okruzhaiuschei sredy, obespechenie ekologicheskoi bezopasnosti, obespechenie ratsionaknogo ispolzovania prirodnyh resursov: terminy, soderzhanie, sootnoshenie. Sbornik materialov vserossiiskih nauchno-praktichekih konferentsii "Sofrino" 1995-2004. T. 1. S. 125.

14. Brinchuk M.M. Rol gosudarstva v obespechenii ekologicheskoi bezopasnosti. Ekologicheskaya bezopasnost: problem, poisk, reshenia. M.

15. Petrova T.V. Technicheskoe regulirovanie kak chast sistemy pravovogo regulirovania otnoshenii v sfere ohrany okruzhaiuschei sredy. Ekologicheskoe pravo. Spestialnyi vypusk. 2005.

16. Kolbasov O.S. Kontseptsia ekologicheskoi bezopasnosti.//Sovetskoe gosudarstvo I pravo. \# 12. 1988. S. 47-55.

17. Ponomarev M.V. Pravovoe regulirovanie ekologicheski bezopasnovo obraschenia s othodami v gorodah.//Zakonodatelstvo I ekonomika. 2013. № 2.

18. Patiukov A.V. Aktyualnye voporosy realizatsii prava cheloveka na blagopriatnuiu okruzhaiuschuu sredu I ekologicheskuiu bezopasnost $v$ Poslanii Prezidenta Rossii Federalnomy Sobraniu Rossiiskoi Federatsii.//Ekologicheskoe pravo.2011. № 5.

19. Platonov Ju.N. Ekologicheskaia komponenta natsionalnoi bezopasnosti Rossii//Zhurnal Rossiiskogo prava. 2011. № 8.

20. Goncharov V.V. Obespechenie ekologicheskoi bezopasnosti v Rossiiskoi Federatsii kak perspektivniy prioritetnyi natsionalnyi proekt//Jurist. 2010. № 5.

Статья поступила в редакцию 5 сентября 2013 г. 